Grana

\title{
13. Lake Saloio (Nazaré, western Portugal)
}

\section{Sandra D. Gomes}

To cite this article: Sandra D. Gomes (2011) 13. Lake Saloio (Nazaré, western Portugal), Grana, 50:3, 228-231, DOI: 10.1080/00173134.2011.579620

To link to this article: https://doi.org/10.1080/00173134.2011.579620

曲 Published online: 09 Jun 2011.

Submit your article to this journal 2

Џll Article views: 170

Citing articles: 1 View citing articles 5 


\title{
CONTRIBUTIONS TO THE EUROPEAN POLLEN DATABASE
}

\section{Lake Saloio (Nazaré, western Portugal)}

\author{
SANDRA D. GOMES \\ Centre for Marine and Environmental Research (CIMA), University of the Algarve, Faro, Portugal
}

\section{Site details}

The Lagoa do Saloio (39 36' 48" N, $9^{\circ} 00^{\prime} 57^{\prime \prime} \mathrm{W}$ ) is a small lake situated $5 \mathrm{~km}$ east of the town of Nazaré in the Valado de Frades forest, central coast of Portugal. The lake is $70 \mathrm{~m}$ above sea level, $270 \mathrm{~m}$ long, $72 \mathrm{~m}$ wide, and oriented west-southwest-eastsoutheast (WSW-ESE). The site is a groundwaterfed, interdunal lake (Queiroz \& Mateus, 2004) located on the border between Plio-Pleistocene sands of the Valado de Frades complex and more recent dunefields (Camarate França \& Zbyszewski, 1963). The local soils are mostly podsols and regisols with fertile alluvial soils distributed along the Alcoa River.

The vegetation is typically Mediterranean, although today the Valado de Frades is a planted Pinus forest covering 1450 ha. Phytogeographically, the region is part of the Gaditan-Algarvian subprovince (Rivas-Martínez et al., 2002), which is a coastal unit with some palaeomediterranean and palaeotropical endemic elements.

The area experiences a Mediterranean climate with warm and dry summers and mild, humid winters. The average annual temperature (1976/1977$2006 / 2007$ ) is $14.4{ }^{\circ} \mathrm{C}$; the annual precipitation is up to $730 \mathrm{~mm}$. This climatic zone is, according to the terminology of Rivas-Martínez et al. (2002), mesomediterranean but in recent years, it tended towards a thermomediterranean climate.

\section{Sediment description}

A core of $500 \mathrm{~cm}$ length was collected in June 2000 by a team from the Portuguese Institute of Archaeology (Lisbon) using a Livingstone corer. The core was recovered from the central part of the lake, where the organic sediment was thickest and water depth was $6 \mathrm{~m}$. Its lithostratigraphic units were as follows:

4-170 cm: organic gyttja, varying from black to brown;

170-278 cm: organic gyttja, with well-defined sand lenses at $219-220 \mathrm{~cm}$ and $225-226 \mathrm{~cm}$;

278-410 cm: dark brown organic gyttja, with medium sand inclusions below $329 \mathrm{~cm}$ and clay content below $347 \mathrm{~cm}$;

$410-436 \mathrm{~cm}$ : organic gyttja, darker toward the base; 436-500 cm: white medium sand.

\section{Dating}

One accelerator mass spectrometer (AMS) radiocarbon date was obtained on Erica wood found at $435.5-436 \mathrm{~cm}$ depth, yielding a carbon- $14\left({ }^{14} \mathrm{C}\right)$ age of $2720 \pm 40$ BP (Beta-235000). A 2-sigma calibration using the INTCAL04 program (Reimer et al., 2004) suggests that this Erica wood dates to $2880-2750$ cal. вP (930-800 вC).

\section{Interpretation}

More than 300 terrestrial pollen grains were identified in each sample and the pollen sum (100\%) includes all pollen grains except hygrophytes and aquatic plants (Figure 1). The concentration of regional pollen varies little throughout the record indicating a relatively constant sedimentation rate. The age ranges for the pollen zones are formulated on that basis and five statistically significant

Correspondence: Sandra Gomes, Algarve University, CIMA Centre for Marine and Environmental Research, Edifício 7, Campus Gambelas, 8005-139 Faro, Portugal. E-mail: sdgomes@ualg.pt 


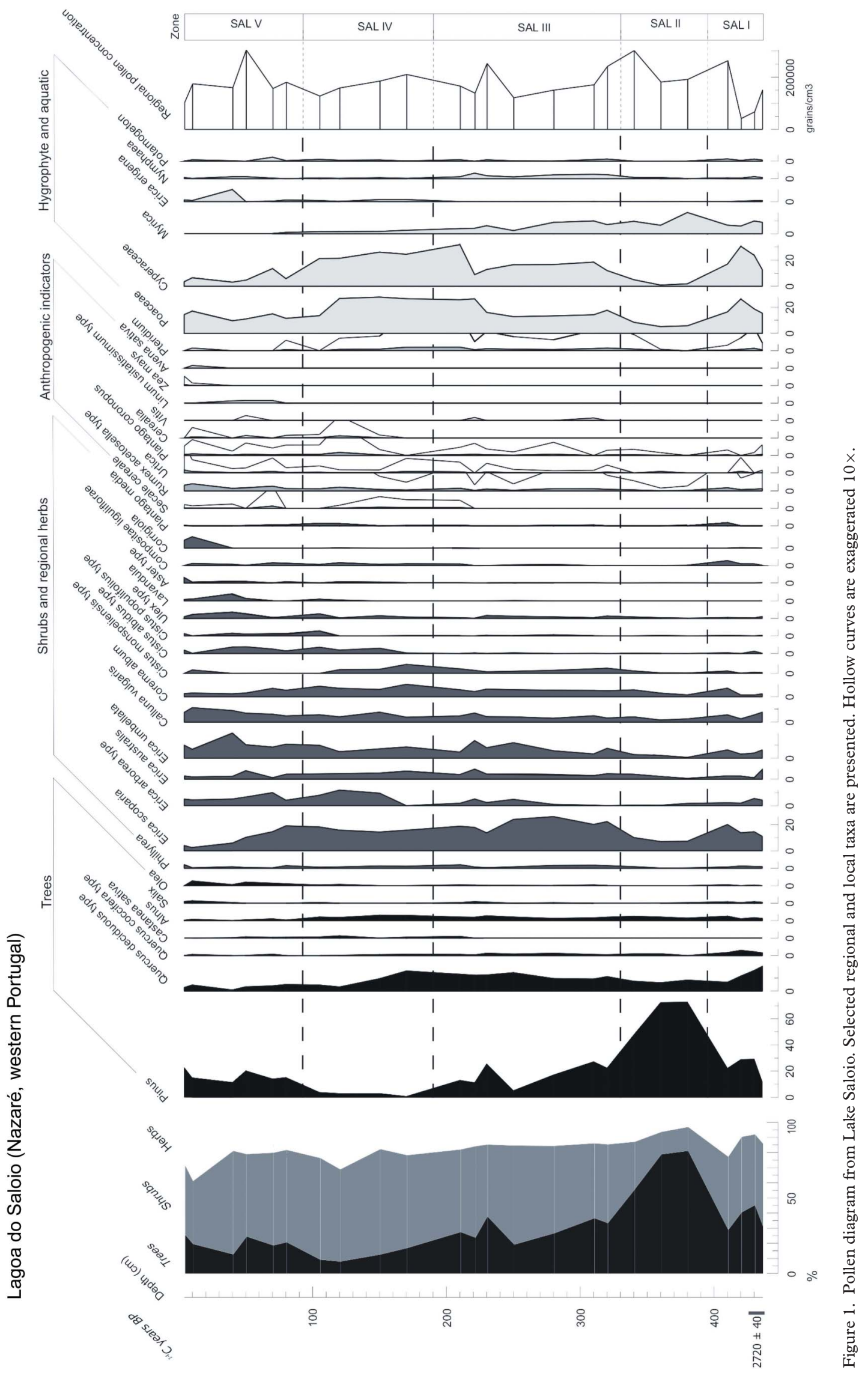


pollen zones were defined using CONISS in Psimpoll (Bennett, 2009).

\section{SAL I (c. 2800-2600 cal. BP)}

This zone has a large percentage of heath [Erica scoparia L. and Corema album (L.) D.Don ex Steud.], which is decreasing towards the end of the zone. Pinus pollen is very abundant and increases as Quercus deciduous-type pollen decreases from its maximum. Pollen from dune vegetation is well represented, as are Poaceae and Cyperaceae pollen. The increase in almost all arboreal pollen values, especially Pinus, may reflect an expansion of forest.

\section{SAL II (c. 2600-2200 cal. BP)}

Arboreal pollen increases in this zone, with the highest values of Pinus pollen (almost 60\%). Alnus pollen also increases. Pollen of sclerophilous shrubs is least abundant in this zone and almost all heath pollen types decrease. Arbutus unedo L. appears as a single pollen grain. Myrica pollen peaks and Poaceae, Cyperaceae, and other aquatic taxa decrease. This period is interpreted as a dry hydrological phase because of the reduction in aquatic pollen and spores. The sandy nature of the sediments of this phase indicates local landscape instability.

\section{SAL III (c. 2200-1300 cal. BP)}

Pinus strongly decreases, with a brief recovery in the middle of the zone. Quercus proportions remain stable. Heath and other shrub pollen types (Cistus albidus L.-type and Ulex-type) exhibit higher values. The pollen of ruderal plants (Rumex acetosella L.type and Plantago coronopus L.) increases. Wetland pollen types are abundant and Poaceae, Cyperaceae, and other aquatic plants (Nymphaea alba L. and Potamogeton) increase at the end of this zone, while Myrica pollen declines. This zone indicates a phase of gradual forest destruction and its replacement with treeless scrub vegetation with Erica scoparia and Erica umbellata L.

\section{SAL IV (c. $1300-700$ cal. BP)}

Arboreal pollen (Pinus and Quercus) proportions are low through this zone, with an evident decrease in Quercus pollen. Pollen representing tall heathlands (e.g. Erica scoparia) decrease while low heathland indicators (Erica umbellata and Calluna vulgaris Salisb.) and sclerophilous shrubs (Cistus sp., Halimium and Ulex-type) increase. Pollen of ruderal plants also increases and pollen of cultivated plants appears, including Avena sativa L., Linum usitatissimum L.-type, and Vitis. Erica erigena R. Ross, semi-terrestrial and aquatic plants are represented in high proportions. Intense deforestation is evident in this zone with the appearance of some anthropogenic indicators of agricultural activity. Linum usitatissimum-type has been used since mediaeval times to make fishing nets. This may explain its appearance here.

\section{SAL V (c. 700 cal. BP-present)}

Pollen of forest trees recovers in this zone: Pinus, gallery forest elements (Salix and Alnus), and also Quercus. Heathland taxa like Erica umbellata increase. Ruderal pollen taxa (Plantago coronopus, Urtica, and Corrigiola) become dominant and pollen of cultivated plants occurs with an increase in Olea pollen, Zea mays L., and Avena sativa. Wetland pollen taxa such as Poaceae and Cyperaceae decrease. Erica erigena pollen peaks.

The top of the record is truncated; therefore, the historically documented establishment of the Valado do Frades pine forest between the thirteenth century and present day (Dinis et al., 2006) is not well represented palynologically. In this zone, the presence of some anthropogenic pollen indicators (Cerealia, Plantago lanceolata L.-type and Rumex acetosella-type) can be interpreted as a strong human impact in this area. The peak of Erica erigena probably indicates local paludification.

\section{Acknowledgements}

The author is very grateful to José Mateus and Paula Queiroz (formerly of the Portuguese Institute of Archaeology, Lisbon) for providing the material and constant advice, without which this work would not have been possible. The author would also like to thank Simon Connor, Randi Danielsen, and Márcia Barbosa for helping with the English revision and for suggestions that improved the manuscript. Financial support for dating was provided by the Portuguese Foundation of Science and Technology (Project PTDC/HAH/71361/2006).

\section{References}

Bennett, K. D. (2009). Psimpoll and pscomb: computer programs for data plotting and analysis, version Psimpoll 4.27. Belfast: Queen's University of Belfast.

Camarate França, J. \& Zbyszewski, G. (1963). Carta geológica de Portugal, na Escala 1:50 000. Notícia explicativa da Folha 26-B, Alcobaça. Lisbon: Direcção Geral de Minas e Serviços Geológicos. Serviços Geológicos de Portugal.

Dinis, J. L., Henriques, V., Freitas, M. C., Andrade, C. \& Costa, P. (2006). Natural to anthropogenic forcing in the Holocene evolution of three coastal lagoons (Caldas da Rainha valley, western Portugal). Quaternary International, 150, 41-51. 
Queiroz, P. F. \& Mateus, J. E. (2004). Paleoecologia Litoral entre Lisboa e Sines do tardiglaciário aos tempos de Hoje. In A. A. Tavares, M. J. F. Tavares, J. L. Cardoso (Eds), Evolução Geohistórica do Litoral Português e Fenómenos Correlativos (pp. 257-304). Lisbon: Geologia, História, Arqueologia e Climatologia Actas, Universidade Aberta.

Reimer, P. J., Baillie, M. G. L., Bard, E., Bayliss, A., Beck, J. W., Bertrand, C. J. H., Blackwell, P. G., Buck, C. E., Burr, G. S., Cutler, K. B., Damon, P. E., Edwards, R. L., Fairbanks, R. G., Friedrich, M., Guilderson, T. P., Hogg,
A. G., Hughen, K. A., Kromer, B., McCormac, G., Manning, S., Ramsey, C. B., Reimer, R. W., Remmele, S., Southon, J. R., Stuiver, M., Tálamo, S., Taylor, F. W., van der Plicht, J. \& Weyhenmeyer, C. E. (2004). IntCal04 terrestrial radiocarbon age calibration, 0-26 cal kyr BP. Radiocarbon, 46, 1029-1059.

Rivas-Martínez, S., Díaz, T. E., Fernández-González, F., Izco, J., Loidi, J., Lousã, M. \& Penas, A. (2002). Vascular plant communities of Spain and Portugal. Addenda to the checklist of 2001. Itinera Geobotanica, 15, 5-922. 